\title{
Linguistic Temporality, Logical Meaning AND NaRRative PersPeCtives: Adverbs ZaI AND you in Modern STANDARd ChINESE
}

\author{
Jens KARLSSON \\ Lund University, Centre for Languages and Literature, Chinese Studies \\ Jens.Karlsson@ostas.lu.se
}

\begin{abstract}
In this paper is presented an inquiry into some aspects of the meaning and usage of two temporal adverbs zai (再) and you (又) in Modern Standard Chinese. A decompositional analysis of the semantic encoding of the adverbs is conducted, aiming to better explain their recorded differences in usage. First, a sketch of some of the fundamental features of linguistic temporality is provided in order to model the structure of temporal semantic information encoded in the adverbs. Non-temporal (logical) meaning such as assertion and inference is also shown to be an important aspect of the semantic content of the adverbs. Adverbs zai and you are shown to encode the same semantic content except for a difference in viewpoint; the first being prospective, the second retrospective. Concrete linguistic examples reflecting the intrinsic semantic encoding of the adverbs are raised and discussed. It is then argued that through combining the decompositional analysis with ideas concerning conceptual analogy, some issues raised by Lu and Ma (1999) regarding the usage of zai and you in past and future settings may be resolved.
\end{abstract}

\section{Keywords}

Chinese, temporal adverbs, decompositional analysis, linguistic temporality, conceptual analogy

\section{Izvleček}

Članek prouči nekatere pomene in načine uporabe časovnih prislovov zai (再) in you (又) v sodobni standardni kitajščini. Za boljše razumevanje razlik v uporabi služi dekompozicijska analiza semantičnih oznak prislovov. Avtor najprej na kratko predstavi osnovne značilnosti izražanja časa v jeziku, na podlagi česar izdela strukturo semantičnih informacij o času, ki jih nosijo prislovi. Tudi ne-časovni (logični) pomeni, kot sta na primer trditev (assertion) in sklepanje (inference), so se izkazali za pomemben del opisa semantike prislovov. Avtor pokaže, da prislova zai in you nosita iste semantične informacije in da je razlika med njima le v pogledu na situacijo - prvi je prospektiven in slednji retrospektiven. Članek v nadaljevanju izpostavi in prouči dejanske primere, ki odražajo notranje semantične zančilnosti prislovov. Nazadnje avtor pokaže, da je s kombinacijo dekompozicijske analize in idej o konceptualni analogiji mogoče razložiti nekatera vprašanja, ki sta jih $\mathrm{v}$ zvezi $\mathrm{z}$ uporabo prislovov zai in you $\mathrm{v}$ preteklih in prihodnjih situacijah že izpostavila Lu and Ma (1999).

\section{Ključne besede}

Kitajščina, časovni prislovi, dekompozicijska analiza, jezikovna časovnost, konceptualna analogija 


\section{Introduction}

There exists a pair of morphemes zai and you in Modern Standard Chinese (MSC) which are normally categorized as temporal adverbs. ${ }^{1}$ Referring to a morpheme as "adverb" concerns its' grammatical function; referring to a morpheme as "temporal" concerns its' semantic information. The previous century saw much debate over the issue of word classes in Chinese, including some controversy as to whether the language can be said to have word classes at all. According to Lu (2003), this debate was especially vivacious during the 1930's, 50's and 80's. These discussions resulted more or less in a consensus among (Chinese) linguists, saying that words in Chinese are categorized into word classes according to (morpho)syntactic properties. The prevalent view on adverbs in this context is that they have the sole function of adverbial modifier. "Strict adverbs are words that conform with the two following criteria: (1) may modify verbs or adjectives; (2) may not modify nouns; may not act a subject, object or predicate." (Zhu, 1961, p. 70-71) This may be contrasted against adjectives for instance, which commonly assume the role of adverbial modifier in addition to several other grammatical roles, including both subject and predicate. Adhering to the view expressed by Zhu (1961), the morphemes zai and you may be considered prototypical adverbs, as their only grammatical function is acting as adverbial modifiers in a predicate clause (Karlsson, 2010).

The question of semantic information carried by temporal adverbs in MSC is not a matter of consensus in the same way as their syntactic function. In the following I present a model of the semantic core content encoded in zai and you. The two adverbs are shown to encode both temporal and non-temporal information. The structure of the temporal information is based on a sketch of the fundamental features of linguistic temporality, which is introduced in the first section. I identify the nontemporal information as logical meaning, the workings of which are introduced in the following section. I then discuss the meaning and function of the two adverbs, presenting empirical data to support the model of their semantic structure which is based on the sections on linguistic temporality and logical meaning. I then discuss some issues concerning the usage of zai and you in narrative contexts which intuitively seem to conflict with their normal usage. I argue for an explanation which considers the intrinsic semantic encoding of the adverbs and the application of associative thinking in the form of conceptual analogy.

\footnotetext{
${ }^{1}$ This paper is in principle an elaboration of ideas first developed in Karlsson (2010). It relies to considerable extent on Lu and Ma (1999) for empirical data, and Karlsson (2010) for theory and method.
} 


\section{Linguistic Temporality}

According to Klein (1994), there is no real consensus concerning the nature of linguistic temporality, referring to "that concept of time which underlies the expression of temporal relations in natural languages" (p. 60). ${ }^{2}$ A typical basic representation of linguistic temporality would probably be something akin to the visual conceptualization of time used in Comrie (1985) (Fig. 1).

\begin{tabular}{l|ll} 
& & \\
\hline PAST & 0 & FUTURE
\end{tabular}

Fig. 1: Basic representation of time (Comrie, 1985, p. 2)

Comrie's representation includes a straight line where the past is located to the left and the future to the right of the present moment (0). It instantiates two of the fundamental features of linguistic temporality as identified by Klein (1994): 'origo' and 'linear order'. Some of the features identified by Klein (1994), like 'linear order' for instance, can be said to be directly derived with logical necessity from even more fundamental characteristics of temporality. Kant (1787) identifies in Critique of Pure Reason time as a "necessary representation, lying at the foundation of all our intuitions" (p. 39). The interesting consequence of this conclusion for the linguistic sciences lies in "the possibility of apodeictic principles of the relations of time, or axioms of time in general, such as: 'Time has only one dimension', 'Different times are not coexistent but successive' (...)" (p. 39). Unidimensionality and unidirectionality are according to this idea a priori given features of temporality, and it would seem that "the expression of temporal relations in natural languages" as referred to by Klein (1994, p. 60) well corresponds with this conception. Relating it to Comries (1985) representation in Fig. 1, it determines that the past, present and future must be arranged in sequential order, constituting different parts of the time axis.

The representation of time depicted in Fig. 1 is intended to show a basic deictic arrangement underlying all tense-systems found in natural languages. Claiming its' universal application corresponds well with the following assumption expressed by Smith $\left(2005^{3}\right)$ : "The deictic pattern - in which Speech Time is central - is a linguistic universal, so far as we know" (p. 3). Reichenbach's (1947) system for a representation of the English tenses is built on the concept of temporal deixis, consisting of Speech

\footnotetext{
${ }^{2}$ Klein (1994) lists seven basic features of linguistic temporality which he believes to be "indispensable" (but not necessarily exhaustive). The features are 'segmentability', 'inclusion', 'linear order', 'proximity', 'lack of quality', 'duration', 'origo'. Some of these features are quite useful for the discussion in this paper.

${ }^{3}$ The year is given according to the printed publication as listed in the references; the page refers to the publication available online, which is also listed in the references.
} 
Time (S), Event Time (E) and Reference Time (R). Although the system was devised with the English tenses in mind, it has proven to be useful for various accounts of temporal expressions cross-linguistically. Smith (2005) notes that "the notion of Reference Time is not dependent on tense, but is basic to temporal location in language. Indeed, it has explanatory value for Mandarin" (p. 10). Given the fact that the system is comprised of two basic features of linguistic temporality - deixis and sequence ('origo' and 'linear order' using Klein's (1994) terminologi) - it is not that surprising to find that it has application in the description of temporal relations other than tense-systems and in languages other than English. As will become evident, the semantic information of zai and you interacts intimately with the deictic temporal structure of sentences they appear in.

\section{Logical and Pragmatic Meaning}

In order to properly account for the meaning and function of many temporal adverbs, including zai and you, identifying the characteristics of their temporal semantic encoding is not enough. In addition to such information, they encode semantic content which is probably best described as logical meaning/information.

(1) 她 还 在 中国

ta hai zai Zhongguo

she still be (in) China

"She is still in China."

The information which is explicitly conveyed - asserted - by the temporal adverb hai is that "she" is still in China at the time when the sentence is uttered. But we may also deduce from the sentence that "she" has been in China for some time prior to when the utterance is made. This information is merely implicitly provided, or inferred. Inferred meaning is conveyed in different forms. Information inferred from the intrinsic meaning of words and propositions is usually labelled "entailment", and defined something like "information logically inferred from single propositions". Information pragmatically inferred from a certain context is usually labelled "implicature". Such information has to do with the extrinsic meaning of words and propositions (Korta \& Perry, 2008; Peccei, 1999).

(2) This is an apple. ${ }^{4}$

Entailment: This is a fruit.

(3) -Are you coming to Agathon's this evening? ${ }^{5}$

-You know how I love listening to Socrates!

Implicature: Yes.

\footnotetext{
${ }^{4}$ Example taken from Karlsson (2010).

${ }^{5}$ Example taken from Karlsson (2010).
} 
While the inferred information in (2) is logically entailed, the answer in (3) is taken to be affirmative despite the fact that there is nothing in the literal meaning of the utterance from which the listener can deduce an affirmative answer. Instead, the affirmative answer is deduced partly through the presupposition that Socrates will be present at the gathering at Agathon's. Presupposition can be seen as a third kind of inferred information belonging somewhere between entailment and implicature, as it may be divided into pragmatic and semantic presupposition. Inferred information such as the presupposition concerning Socrates in (3), on which the affirmative implicature relies, is derived completely from context and therefore a pragmatic presupposition. Semantic presuppositions provide inferred information directly from individual words and propositions stripped of further context. Semantic presuppositions can in turn be divided into existential and logical presuppositions (Simpson, 1993).

(4) Guan Yu doesn't serve Cao Cao anymore.

Existential presupposition: There exists (existed) someone by the name of Cao Cao.

Logical presupposition: Guan Yu used to serve Cao Cao.

Just as we may deduce as a logical presupposition in example (4) that Guan $\mathrm{Yu}$ used to serve Cao Cao, in example (1) we may deduce as a logical presupposition that "she" has been in China for some time already when the utterance is made, while the information that she is in China when the utterance is made is asserted. Without the presupposed information the utterance doesn't make sense; it is simply part of the intrinsic semantic encoding of the adverb. The kind of inferred information ascribed to the adverbs dealt with in this paper is all of the type logical presupposition.

\section{Temporal Adverbs zai and you}

The fact that the adverbs zai and you convey some sort of temporal notion is intuitively clear from looking at examples like the following. ${ }^{67}$

（5）去过了还可以再去

qu guo le hai keyi zai qu

go GUO LE still may again go

"Having gone (there) before, you can still go a second time."

(6) 你 敢 再 赛 - 场 吗

ni gan zai sai yi chang ma

you dare again compete one CLF MA

"Do you dare compete one more time?"

\footnotetext{
${ }^{6}$ Examples 5-8 taken from Xiandai Hanyu Babai Ci (1999).

${ }^{7}$ Adverbs zai and you also express other temporal notions such as continuation, as well as some modal meanings. Due to limited space, these notions are not discussed in the present paper.
} 
（7）这个人昨天来过今天 又 来了 zhe ge ren zuotian lai guo jintian you lai le this CLF person yesterday come GUO today again come LE "This person was here yesterday, and came again today."

（8）你又生 我的气 了 ni you sheng wo de qi le you again get/have I DE anger LE "(Now) you became angry with me again."

It is clear from examples (5) through (8) that one salient feature of the semantic information carried by zai and you is the notion of repetition. In examples (5) and (7), the core predicates $q u$ "go" and lai "come", modified by the adverbs zai and you respectively, are even explicitly provided in both clauses. In examples (6) and (8), the core predicates sai "compete" and shengqi "become angry" are only provided on one instance, but nevertheless the idea that the core predicate has been realized already (at least) once before is clearly conveyed. This indicates that the adverbs zai and you intrinsically encode the notion of repetition of the modified core predicate (as the core predicate is understood as being repeated despite only explicitly provided once). Repetition as a temporal phenomenon can be further analysed as the sequential arrangement of (at least) two separated points or stretches on the time axis. I will therefore argue that the adverbs zai and you intrinsically encode two separate reference times at which the core predicate modified by the adverbs occurs. I shall call these times E1 and E2.

While the instance of the core predicate directly modified by the adverb is explicitly asserted to be realized, the previous instance(s) of the core predicate is taken for granted to having been realized already before. Thus we see that the adverbs also encode non-temporal information as discussed in section 3. I argue that they encode an assertion that the core predicate modified by the adverb occurs at E2, and also encode a logical presupposition that the core predicate occurs (occurred) at E1.

We have seen so far that zai and you encode two identical sets of semantic notions: (1) A sequential arrangement of two separate times E1 and E2, at which the modified core predicate occurs. (2) Assertion directed at the realization of the core predicate at E2, and logical presupposition ${ }^{8}$ directed at the realization of the core predicate at the E1. In Fig. 2, a schematic model of the shared semantic structure of zai and you is presented.

\footnotetext{
${ }^{8}$ Henceforth referred to only as presupposition for the sake of convenience.
} 


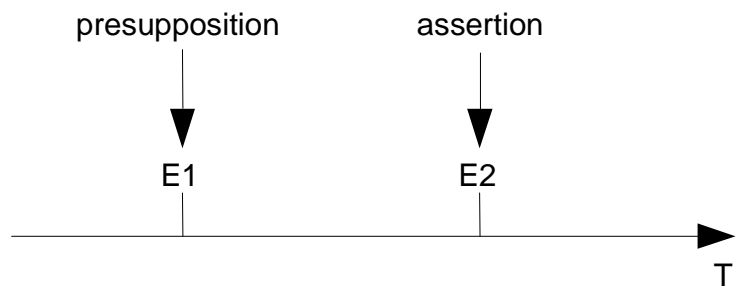

Fig. 2: Model of the shared semantic structure of zai and you

\subsection{The Viewpoint Component}

Despite the obvious similarities in the semantic encoding, it is well documented that zai and you display certain grammatical disparities. "The two can both be used for repeated acts. 'Zai' is used for acts which will be repeated, 'you' is used for acts that are already repeated." (Xiandai Hanyu Xисі Cidian, 1998, p. 719) "When expressing repetition or continuation of an action, 'zai' is used for unrealized ones [actions], 'you' is used for realized ones [actions]." (Xiandai Hanyu Babai Ci, 1999, p. 644) I argue that this difference must be attributed to an additional semantic component. The model in Fig. 2 cannot be complete, as it ascribes the exact same semantic structure to both adverbs, and can therefore not account for the systematic discrepancies in grammatical function noted in several works as cited above. Instead, I propose that these adverbs encode an additional semantic component in the form of a viewpoint, to which the semantic structure modelled in Fig. 2 is related positionally. A viewpoint can be understood simply as a deictic centre in the temporal structure; a "vantage point" on the time axis. In the case of $z a i$, the viewpoint is located between E1 and E2. It is placed subsequent to E1 because the realization of the core predicate at that time is presupposed (and therefore naturally located prior to the viewpoint). The assertion encoded in the adverb is directed at E2, but the data suggest that the core predicate is typically understood as unrealized at that time. Therefore I argue that the viewpoint component in zai is located between E1 and E2. The presupposed information is taken for granted and need not any direct attention, so to speak. The asserted information however, is the focal point of the whole semantic structure, and therefore naturally the point towards which the viewpoint is aiming. Therefore the perspective of the viewpoint is prospective. Fig. 3 is a model of the semantic structure of $z a i$. 


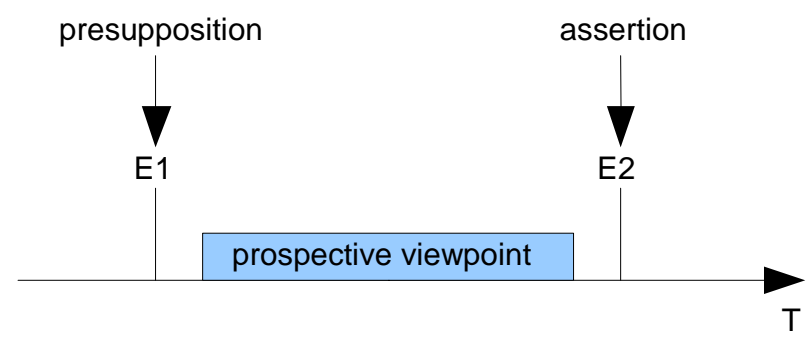

Fig. 3: Semantic structure of zai

With you, the situation is different. The data suggest that the core predicate is typically understood as realized at E2. Therefore I argue that the viewpoint component in you is placed subsequent to E2. ${ }^{9}$ The asserted information is always the focal information of the semantic structure, and therefore the viewpoint is in the case of you retrospective. Fig. 4 is a model of the semantic structure of you.

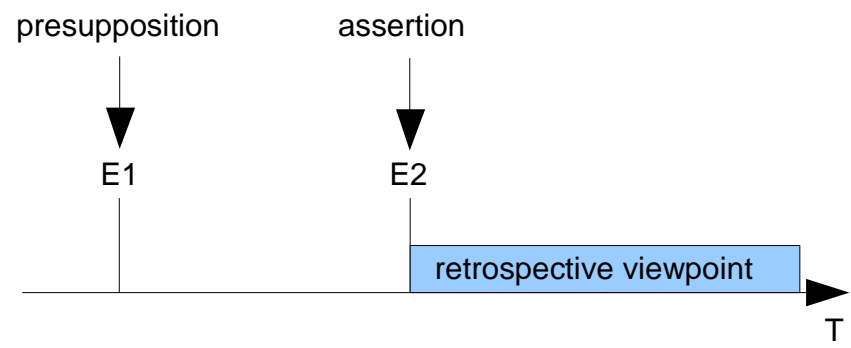

Fig. 4: Semantic structure of you

Due to the intrinsic arrangement of semantic components, with a prospective viewpoint located between E1, at which the core predicate is presupposed to be realized, and E2, at which the core predicate is asserted to be realized, the typical temporal structure of a basic declarative sentence with zai is one where E1 is located in the past, E2 located in the future, and the viewpoint coinciding with S. S being the default orientation point, the basic declarative sentence centres temporally around it, and the intrinsic semantic structure of zai is "distributed" in accordance, with the viewpoint coinciding with $S$, while E1 is located prior to $S$ (in the past) and E2 is located subsequent to $\mathrm{S}$ (in the future). On the contrary, you is normally not compatible

\footnotetext{
${ }^{9}$ It seems that in examples similar to (8), the core predicate can be interpreted as being realized virtually at the time of the utterance. Therefore the viewpoint is really located subsequent to or no earlier than at E2, which is shown in Fig. 4.
} 
with such sentences due to the fact that its viewpoint is retrospective and located after (or at) E2. Instead it is readily used in settings located wholly prior to S, i.e. in the past. These circumstances are exemplified in (9), where only zai and not you is grammatical, and (10), where only you and not zai is grammatical. ${ }^{10}$

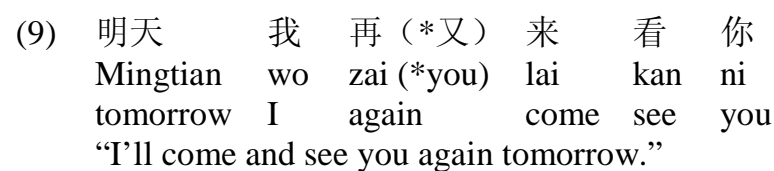

(10) 妈 那篇 课文 我刚才 又 (*再) 背了一遍 Ma na pian kewen wo gangcai you (*zai) bei le yi bian mum that CLF text I just now again learn LE one time "Mum, I went through (in order to learn by heart) that text again just now."

\subsection{Temporal Adverb zai in Past Settings}

As noted by Lu and Ma (1999), zai may be used in a past setting, if the sentence depicts a hypothetical perspective.
(11) 昨天
如果 我 再 (*又) 看
看一
遍 就 记住
了
Zuotian ruguo wo zai (*you) kan yi bian jiu jizhu $\mathrm{l}^{11}$ yesterday if I again read one time JIU remember LE
"I would have remembered it had I only read it one more time yesterday."

Since $\mathrm{S}$ is the default orientation point of the sentence, the prospective viewpoint cannot normally be applied in a past setting; the prospective viewpoint is naturally directed towards a time subsequent to the default orientation point $\mathrm{S}$. But the hypothetical perspective relativizes these circumstances, as E2 is never explicitly realized but merely hypothetically realized. Therefore zai can still be used to express a prospective viewpoint directed towards E2 even though E2 is located prior to S. The hypothetical perspective functions as a mitigating factor extenuating the inherent contradiction between the two concepts past narrative and prospective viewpoint. Fig. 5 shows a temporal interpretation of (11). The time of the utterance is $\mathrm{S}$. The Reichenbachian reference time $\mathrm{R}$ is set by zuotian 'yesterday'. The temporal and logical structure intrinsically encoded in zai is distributed around $\mathrm{R}$, and the prospective viewpoint (roughly) coincides with this time. ${ }^{12}$

\footnotetext{
${ }^{10}$ Examples (9) and (10) taken from $\mathrm{Lu}$ and $\mathrm{Ma}$ (1999).

${ }^{11}$ Example (11) taken from Lu and Ma (1999).

${ }^{12}$ The prospective viewpoint is located somewhere between E1 and E2, and E1 and E2 are located somewhere within the scope defined by R. The most important aspect of the figure is to show the relationship between the "outer" temporal reference structure ( $\mathrm{S}$ and $\mathrm{R}$ ) and the "inner" temporal and logical structure of zai. Since E2 is merely hypothetically realized, the semantic information of zai can be applied in a past setting.
} 


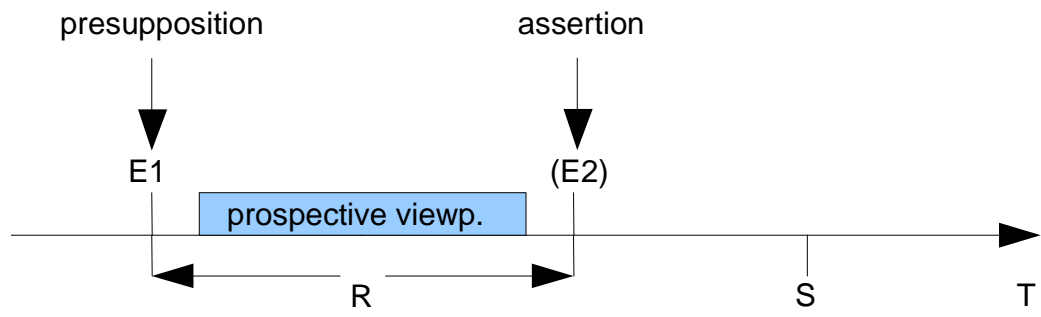

Fig. 5: Temporal interpretation of (11)

As a contrast, you is readily applied in a past setting, as the retrospective viewpoint then coincides with $\mathrm{S}$, with $\mathrm{E} 1$ and $\mathrm{E} 2$ both located prior to $\mathrm{S}$ and understood as realized. The temporal interpretation of such an example (12) is given in Fig. 6.

(12) 我昨天 又 看了一遍 wo zuotian you kan le yi $\operatorname{bian}^{13}$

I yesterday again read LE one time

"I read it again one more time yesterday."14

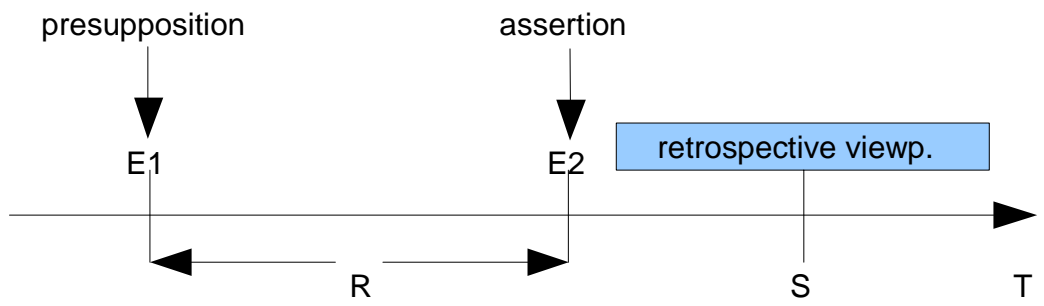

Fig. 6: Temporal interpretation of (12)

\subsection{Temporal Adverb you in Future Settings}

Also noted by Lu and Ma (1999), there are some circumstances under which you may be used in a future setting: (1) When the situation is understood as cyclic and recurrent. (2) When the situation depicts an undesirable scenario. Using you in a future

\footnotetext{
${ }^{13}$ Example from my own hand.

${ }^{14}$ Strictly speaking the more natural interpretation of example (12) is that E1 occurs prior to R, i.e. at a day earlier than zuotian 'yesterday', but most importantly the intrinsic semantic structure of you can readily be distributed around the "outer" temporal reference structure ( $\mathrm{S}$ and $\mathrm{R}$ ), as the retrospective viewpoint coincides with $\mathrm{S}$, and $\mathrm{E} 1$ and $\mathrm{E} 2$ are both realized and located prior to $\mathrm{S}$.
} 
setting is in the normal case a violation of the intrinsic semantic encoding of the adverb, as the viewpoint is retrospective. It can thus not be properly applied when E2 is located subsequent to S. I shall argue that the model of the semantic encoding of you, paired with insights concerning conceptual analogy, help make significant progress towards explaining this problem.

\subsubsection{Cyclic events}

We have seen that since you encodes retrospective viewpoint, it is naturally compatible with situations to which such a viewpoint can be applied. The most obvious example is a situation located in the past. These circumstances can be somewhat relativized if the situation modified by you is located in the future, but still perceived as certain to occur in some sense. Cyclic events are perceived as certain to occur, even when located in the future. Example (13) shows that in sentences depicting cyclic events located in the future, only you is grammatical and not zai.

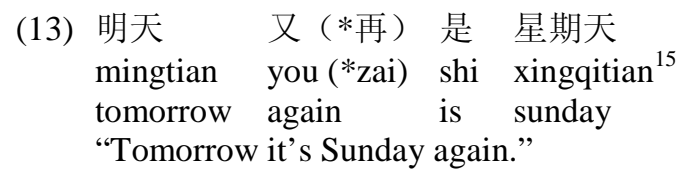

Cyclic events occur again and again in accordance with a law of regularity and can therefore be anticipated with certainty even when the next occurrence is located in the future. I argue that the conceptual analogy between retrospectivity and certainty makes you compatible with situations depicting a future occurrence of a cyclic event. As shown in (13), zai is ungrammatical in such a context, indicating that the perception of recurrent regularity inhibits the application of a prospective viewpoint, since it requires a stronger notion of uncertainty. Similarly to the case of zai used in past settings, where the hypothetical perspective functions as a mitigating factor extenuating the inherent contradiction between the two concepts past narrative and prospective viewpoint, the certainty associated with cyclic events extenuates the inherent contradiction between the two concepts future narrative and retrospective viewpoint.

\subsubsection{Undesirable scenarios}

Lu and Ma (1999) present empirical data showing that you may be used to modify undesirable scenarios located in the future. ${ }^{16}$ If the scenario is not undesirable, only zai and not you may be used. These circumstances are shown in (14) and (15). ${ }^{17}$

\footnotetext{
${ }^{15}$ Example from my own hand.

${ }^{16}$ There are no restrictions to the usage of zai in such contexts, as a future setting is its natural environment.

${ }^{17}$ Examples taken from Lu and Ma (1999); (14) slightly altered.
} 
(14) 要是 明天 再（又）吃面条我就吃倒胃口了 Yaoshi mingtian zai (you) chi miantiao wo jiu chidao weikou le if tomorrow again eat noodles I JIU lose appetite LE "If I have noodles again tomorrow I'm gonna lose appetite."

(15) 如果 明天 再 (*又) 吃 面条就 好了 Ruguo mingtian zai (*you) chi miantiao jiu hao le if tomorrow again eat noodles JIU good LE "It would be great if we are having noodles again tomorrow."

I believe that the key to explaining why you may also modify situations depicting future undesirable scenarios lies in the realm of conceptual analogy, just as in the case with you modifying cyclic events located in the future. Retrospectivity and certainty are conceptually closely resemblant, as are certainty and unavoidability. If a situation is located in the future, and also certain to occur (like the next occurrence of a cyclic event), that means it is unavoidable. ${ }^{18}$ Something which is perceived of as unavoidable is very likely to also be perceived as desirable to avoid. Such a situation is necessarily undesirable. This does not mean, of course, that the future occurrence of a cyclic event must be undesirable. The reason that you may modify such situations is simply due to the conceptual resemblance between retrospectivity and certainty, and there is no need to invoke additional analogous concepts in order to explain why you may do so. What is does mean, is that since there is a clear chain of conceptually interrelated notions linking the concepts of retrospectivity and undesirability to each other, a possibility is created for the viewpoint encoded in you to be transferred from the concept of retrospectivity onto the concept of undesirability through analogous association. This chain of interrelated concepts is visualized in Fig. 7.

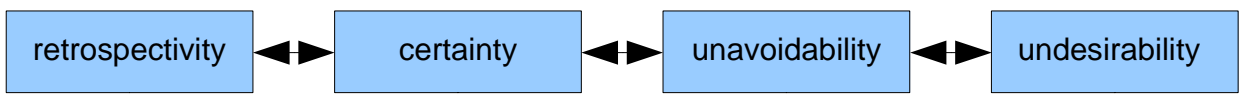

Fig. 7: Chain of conceptually interrelated concepts

The reason why you may be used in a future setting modifying undesirable scenarios is due to basically the same mechanism explaining why you may modify cyclic events located in the future. The later case is arguably somewhat more easily understood, as the conceptual analogy between retrospectivity and certainty seems rather direct. The concept of undesirability is probably conceptually less directly analogous to the concept of retrospectivity, and the connection is reached through additional intermediate concepts.

\footnotetext{
${ }^{18}$ Or in any case perceived of as unavoidable.
} 


\section{Summary}

The inquiries in this paper showed how a decompositional analysis of the adverbs $z a i$ and you reveals that these morphemes encode both temporal and non-temporal information. The analysis also showed that the intrinsic semantic encodings of zai and you are virtually identical, as they encode the exact same semantic components. It was argued that the documented differences in grammatical use are due to a discrepancy in the arrangement of the semantic components; zai encoding a prospective viewpoint located between E1 and E2; you encoding a retrospective viewpoint located after or no earlier than at E2. Through combining the decompositional analysis of the adverbs with ideas concerning conceptual analogy, explanations to the usage of zai and you in unnatural contexts could be provided.

\section{Abbreviations}

CLF Classifier

DE Subordinator; nominalizer

GUO Experiential marker

JIU Connective

LE Verb/sentence-final particle

MA Interrogative particle

\section{References}

Comrie, B. (1985). Tense. Cambridge University Press.

Davis, W. (2010). Implicature. In The Stanford Encyclopedia of Philosophy, E Zalta, ed. (2010 edition) Retrieved from http://plato.stanford.edu/entries/implicature/.

Grice, P. (1989). Logic and Conversation. In Studies of the Way of Words. Harvard University Press.

Kant, I. (1787). Critique of Pure Reason, (revised edition). Retrieved from http://www.gutenberg.org/etext/4280.

Karlsson, J. (2010) Temporal Adverbs in Modern Standard Chinese - A Decompositional Inquiry. Lund University.

Klein, W. (1994). Time in Language. Routledge.

Korta, K. \& Perry, J. (2008). Pragmatics. In Stanford Encyclopedia of Philosophy, E. Zalta (ed.), (fall 2008 edition). Retrieved from http://plato.stanford.edu/entries/pragmatics/.

Lu, J. \& Ma, Z. (1999). (关于表重复的副词“文”“再”“还”) Guanyu biao chongfu de fuci “you” “zai” "hai” [Concerning the adverbs “you” “zai” “zai”" expressing repetition]. In: (现代汉 语虚词散论) Xiandai Hanyu Xuci Sanlun [Various Treatments of Function Words in Modern Chinese], (revised edition). Language and Literature Press. 
Lu, J. (2003). (现代汉语语法研究教程) Xiandai Hanyu Yufa Yanjiu Jiaocheng [A Course in Modern Chinese Grammar Research]. Peking University Press.

Lü, S., ed. (1999). (现代汉语八百词) Xiandai Hanyu Babai Ci [Eight Hundred Words in Modern Chinese]., (revised and enlarged edition). Commercial Press. Original edition 1980.

Peccei, J. S. (1999). Pragmatics. Routledge.

Reichenbach, H. (1947). Elements of Symbolic Logic. Macmillan.

Simpson, P. (1993). Language, Ideology and Point of View. Routledge.

Smith, C. S. and Erbaugh, M. S. (2005). Temporal Interpretation in Mandarin Chinese. In Linguistics: an interdisciplinary journal of the language sciences, 43 , no. 4 . Retrieved from http://uts.cc.utexas.edu/ carlota/papers/S\%26E\%202005.pdf.

Xiandai Hanyu Xuci Cidian (现代汉语虚词词典) [A Dictionary of Function Words in Modern Chinese] (2004). Peking University Press. Hou, X., ed. Original edition 1998.

Zhu, D. (1961). (现代汉语语法研究) Xiandai Hanyu Yufa Yanjiu [Research on Modern Chinese Grammar]. Commercial Press. 